\title{
Application of science and technology to increase the small production capacity of cake market products
}

\author{
Elita Dewi ${ }^{{ }^{*}}$, Berlianti $^{2}$ \\ ${ }^{1}$ Dosen Prodi Ilmu Administrasi Negara FISIP Universitas Sumatera Utara \\ ${ }^{2}$ Dosen Prodi Ilmu Kesejahateran Sosial FISIP Universitas Sumatera Utara \\ *Email: elitadewi0407@gmail.com *
}

\begin{abstract}
One of the many developing UMKM today is the snack business. Snack business is a household-scale business that has very good opportunities for now and in the future. Market demand for snacks continues to flow. Seeing snack lovers, not only children, but also teenagers, adults, to the elderly. So it is not surprising that the food business that is often served as a distraction while doing this activity is often flooded with customers. Making this snack business opportunity becomes more wide open.

The low production capacity that is owned makes this business less developed. Besides that the equipment used is also simple and is still traditional in nature, so it takes a long time and is very draining. For this reason, science and technology is needed that will make the production process easier and cheaper.

In connection with this, it is felt necessary to provide assistance and training to improve the capacity of community service partners. Besides improving the marketing strategy so that it has the ability to market the market snacks in production, so as to create and have a lot of marketing networks. Training is needed to enable entrepreneurs to calculate total sales revenue and total costs so that they are able to know how much profit is earned per unit of production.

It is expected that after the mentoring, the partners will become more knowledgeable, able to apply this knowledge in their daily work and transmit this knowledge to other entrepreneurs.
\end{abstract}

\section{Keyword: UMKM, Productivity, Increased Income}

\begin{abstract}
Abstrak
Salah satu UMKM yang banyak berkembang saat ini adalah bisnis makanan ringan. Bisnis makanan ringan merupakan bisnis berskala rumah tangga yang memiliki peluang sangat bagus untuk saat ini maupun yang akan datang. Permintaan pasar untuk makanan ringan terus mengalir. Melihat penikmat makanan ringan, tidak hanya anak-anak, tetapi juga remaja, dewasa, hingga orang tua. Maka tidak mengherankan jika pelaku bisnis makanan yang sering disajikan sebagai selingan saat melakukan kegiatan ini sering kali kebanjiran pelanggan. Membuat peluang bisnis makanan ringan ini menjadi semakin terbuka lebar.

Rendahnya kapasitas produksi yang dimiliki membuat usaha ini kurang berkembang. Disamping itu peralatan yang digunakan juga sederhana dan masih bersifat tradisional, sehingga memakan waktu yang cukup lama dan sangat menguras tenaga. Untuk itulah diperlukan sentuhan iptek yang akan membuat proses produksinya menjadi lebih mudah dan murah.

Sehubungan dengan hal tersebut, maka dirasa perlu diberikan pendampingan dan pelatihan untuk meningkatkan kapasitas mitra pengabdian. Selain itu meningkatkan strategi pemasaran agar memiliki kemampuan dalam memasarkan kue jajanan pasar yang di produksi, sehingga mampu menciptakan dan memiliki banyak jaringan pemasaran. Perlunya diberikan pelatihan yang memampukan pengusaha menghitung total pendapatan penjualan dan total biaya sehingga mampu mengetahui berapa laba yang diperoleh per satuan produksi.

Diharapkan setelah pendampingan, para mitra menjadi lebih meningkat pengetahuannya, mampu mengaplikasikan pengetahuan tersebut dalam pekerjaan sehari-harinya dan menularkan pengetahuan tersebut kepada pengusaha yang lain.
\end{abstract}

\section{Kata Kunci: UMKM, Produktivitas, Peningkatan Pendapatan}




\section{PENDAhuluan}

Usaha kecil atau lebih dikenal dengan UMKM saat ini perlu dikembangkan dan dipertahankan, mengingat manfaat yang diperoleh. Usaha kecil dikembangkan dengan harapan dapat meningkatkan penyerapan tenaga kerja dan meningkatkan pendapatan untuk kemudian dialokasikan pada pengeluaran rumah tangga. Pembinaan dan pengembangan usaha kecil yang baik akan memperbesar sumbangannya bagi perekonomian nasional pada umumnya dan memberikan sumbangan bagi daerah dimana usaha kecil itu tumbuh dan berkembang.

Di samping berperanan besar dalam menyerap tenaga kerja, usaha kecil juga berperan dalam meningkatkan penghasilan masyarakat. Ketiadaan dukungan merupakan kendala perkembangan usaha kecil seperti akses terhadap teknologi dan peningkatan sumber daya manusia. Tujuan akhir dari usaha ini adalah meningkatkan kesejahteraan masyarakat kalangan bawah yang kurang beruntung pada khususnya dan masyarakat luas pada umumnya.

Namun meskipun UMKM ini memiliki peran penting dan memberikan kontribusi yang cukup besar, bisnis UMKM ini juga masih memiliki kelemahan saat beroperasi sehingga pemerintah perlu untuk memberikan dukungan dan sokongan agar bisnis UMKM ini bisa berjalan dengan lancar. Beberapa permasalahan yang bisa kita jumpai pada bisnis UMKM ini adalah seperti kesulitan pemasaran, keterbatasan SDM, kesulitan bahan baku, keterbatasan inovasi dan teknologi, hingga kesulitan akses ke sumber pembiayaan yang cukup terbatas. Dengan mengetahui beberapa permasalahan tersebut, maka sudah semestinya pemerintah untuk memperhatikan bisnis kecil ini karena jika berkembang maka negara juga akan mendapatkan keuntungan pemasukan.

Salah satu UMKM yang banyak berkembang saat ini adalah bisnis makanan ringan. Bisnis makanan ringan merupakan bisnis berskala rumah tangga yang memiliki peluang sangat bagus untuk saat ini maupun yang akan datang. Permintaan pasar untuk makanan ringan terus mengalir. Melihat penikmat makanan ringan, tidak hanya anak-anak, tetapi juga remaja, dewasa, hingga orang tua. Maka tidak mengherankan jika pelaku bisnis makanan yang sering disajikan sebagai selingan saat melakukan kegiatan ini sering kali kebanjiran pelanggan. Membuat peluang bisnis makanan ringan ini menjadi semakin terbuka lebar.

Negara kita kaya dengan berbagai jenis makanan ringan atau camilan. Beragamnya jenis makanan ringan di Indonesia dimulai dari keripik, gorengan, siomay, batagor dan aneka ragam kue basah yang dijual dengan berbagai variasi harga. Makanan ringan atau camilan ini merupakan juga makanan tradisional Indonesia. Maka tidak mengherankan jika makanan ringan ini lazimnya kita jumpai dijual di pasar-pasar. Sehingga sering juga disebut sebagai penganan jajanan pasar.

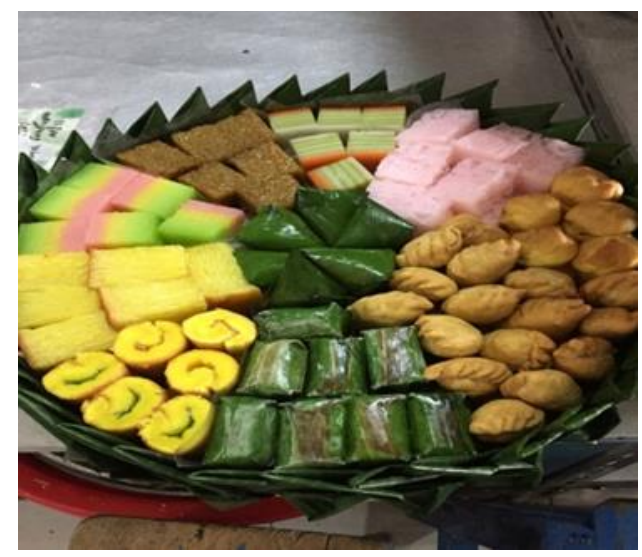

Gambar 1. Aneka ragam kue jajanan pasar

Mitra pengusaha dalam pengabdian ini, Lestari dan Kamsia, sudah menjalankan usahanya dalam beberapa tahun belakangan ini. Namun hasil yang didapatkan dirasa masih jauh dari cukup. Terbatas hanya pada sekedar menutupi kebutuhan di dapur (makan keluarga) saja. Untuk bisa 
menutupi kebutuhan pendidikan anak, kesehatan dan kebutuhan lainnya sangatlah jauh dari harapan. Hal ini terlihat karena pemasaran dari produk kue jajanan pasar yang di hasilkan hanya terbatas pada tetangga dan daerah sekitar tempat tinggal mitra. Sungguh sangat disayangkan. Karena ditinjau dari rasa kue yang mereka produksi sungguh enak, tidak kalah dari kue sejenis yang dijajakan di pasar tradisional maupun toko-toko kue yang tersebar di banyak tempat di Kota Medan.

Disamping itu proses produksi yang dilakukan oleh mitra masih bersifat konvensional, sehingga tidak mudah untuk dapat meningkatkan kapasitas produksinya. Belum ada sentuhan peralatan-peralatan atau teknologi modern yang bisa memudahkan pekerjaan sehingga mampu untuk meningkatkan volume produksi.

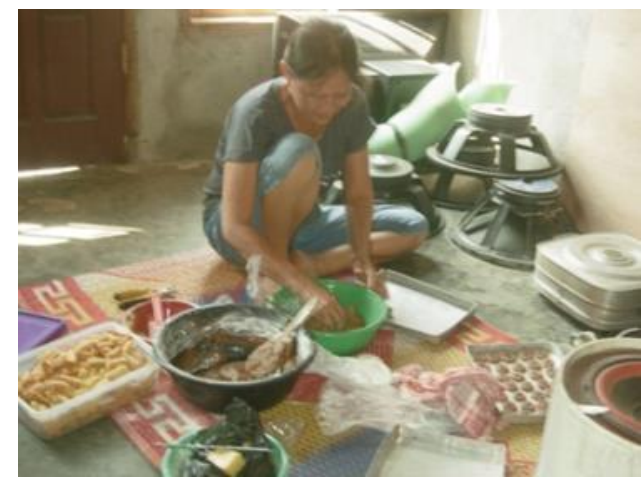

Gambar 2. Proses produksi kue jajanan pasar oleh mitra UMKM

Rendahnya pengetahuan dan keterampilan juga menjadi salah satu faktor membuat usaha kue ini kurang berkembang. Ini terlihat dari masih kurang variatifnya produk kue yang dihasilkan oleh mitra pengusaha. Disamping itu kemasan yang kurang memadai dan menarik juga diyakini membuat usaha kue ini serasa jalan di tempat.

Kurangnya modal dan rendahnya pengetahuanlah yang membuat mitra sulit untuk mengembangkan usahanya. Inilah yang membuat tim pengusul merasa tertarik untuk melakukan pengabdian pada masyarakat yang diberi judul "Penerapan IPTEK Untuk Meningkatkan Kapasitas Produksi UMKM Produk Kue Jajanan Pasar".

\subsection{Permasalahan Mitra}

a. Rendahnya kapasitas mitra UMKM dalam menghasilkan kue jajanan pasar yang sehat dan higienis.

b. Rendahnya pengetahuan dan wawasan mitra UMKM dalam melihat peluang pemasaran. Pengusaha melihat terbatas di pasar lokal/sekitar rumah saja.

c. Rendahnya kapasitas mitra pengusaha dalam memproduksi berbagai jenis aneka ragam kue jajanan pasar.

d. Rendahnya kapasitas mitra pengusaha dalam mengadon bahan baku sehingga tidak bisa meningkatkan produksi kue jajanan pasar.

e. Rendahnya pengetahuan mitra pengusaha UMKM dalam memproduksi secara efektif dan efisien melalui perhitungan laba dan analisis biaya yang lebih baik, sehingga dengan signifikan mampu meningkatkan pendapatan mitra pengabdian. 


\subsection{SOLUSI DAN TARGET LUARAN}

\subsubsection{Solusi yang Ditawarkan}

Untuk meningkatkan produktivitas, maka dirasa perlu melakukan pengabdian kepada mitra dengan cara :

1. Ceramah dan diskusi, untuk mengetahui lebih jelas permasalahan dasar pengusaha kue jajanan pasar, sehingga bisa diberikan solusi masalah.

2. Mengadakan sosialisasi arti penting home industri usaha kue jajanan pasar. Meyakinkan mitra bahwa kue jajanan pasar dengan proses produksi yang efektif dan efisien akan mampu memperluas pasar.

3. Memfasilitasi untuk melaksanakan pelatihan dengan mengundang ahli tata boga agar mitra pengusaha memiliki kemampuan menghasilkan kue jajanan pasar yang lebih variatif, sehat dan higienis.

4. Memfasilitasi untuk melaksanakan pelatihan penggunaan mixer lebih besar dan oven yang baik, diharapkan dapat meningkatkan kapasitas produksi sehingga meningkatkan produktivitas.

5. Melatih pengusaha kue jajanan pasar agar mampu memproduksi secara efektif dan efisien melalui perhitungan laba dan analisis biaya yang lebih baik, sehingga mampu meningkatkan pendapatan pengusaha.

\section{Target luaran}

Luaran yang dihasilkan setelah selesainya kegiatan pengabdian pada masyarakat ini adalah :

1. Meningkatnya kapasitas mitra dalam memahami persoalan-persoalan yang mereka hadapi dan mampu menghadapinya.

2. Meningkatnya kapasitas mitra usaha dalam memproduksi kue jajanan pasar lebih sehat dan higienis.

3. Meningkatnya produksi dan produktivitas mitra pengusaha dalam menghasilkan kue jajanan pasar lewat produk yang lebih variatif.

4. Meningkatnya kapasitas mitra pengusaha dalam memproduksi kue jajanan pasar lebih banyak dan cepat.

5. Meningkatkan pengetahuan dan wawasan mitra pengusaha dalam melihat peluang pemasaran sehingga mampu menembus pasar yang lebih luas.

6. Menambah kemampuan dan skill pengusaha kue jajanan pasar dalam menghitung total pendapatan, mengetahui faktor-faktor yang menentukan besarnya pendapatan. Mampu menghitung total biaya dan mengetahui cara untuk meminimalkan biaya produksi serta menghitung keuntungan per satuan produksi dan total keuntungan per bulan.

\section{METODE PELAKSANAAN}

\subsection{Metode Pendekatan}

Metode pendekatan yang dilakukan selama melakukan pengabdian kepada mitra adalah dengan cara melakukan ceramah, sosialisasi, pelatihan, bimbingan dan pendampingan terhadap pengusaha yang menjadi mitra. Pengukuran perubahan terhadap perilaku mitra dapat dilihat dari perilaku mitra yang berubah menjadi terbiasa dan mampu menghasilkan kue jajanan pasar dengan cara yang efisien dan dengan kualitas yang bagus. Mitra menjadi mengetahui teknik melakukan kegiatan produksi yang sehat, higienis, efektif dan efisien. Melalui kegiatan pengabdian ini mitra juga diharapkan semakin memiliki mental kewirausahaan serta mampu meningkatkan penjualan dan wilayah pemasaran setelah diberikan pelatihan. 


\subsection{Rencana Kegiatan}

Rencana kegiatan yang akan dilakukan untuk pemecahan masalah adalah dengan tahapan sebagai berikut :

1. Sosialisasi

Sosialisasi dilakukan kepada mitra pengabdian di kediaman yang sekaligus sebagai tempat usaha mitra. Materi sosialisasi adalah keberadaan dan makna bisnis kuliner rumahan bagi mitra abdi, pentingnya menjaga higienis dan kesehatan produk kue, serta meningkatkan produksi dan produktivitas, peningkatan pendapatan dan kesejahteraan mitra abdi melalui usaha kue jajanan pasar.

Ceramah dan diskusi

2. Setelah kegiatan sosialisasi dilakukan tim pengabdian akan melakukan ceramah dan diskusi tentang rencana kegiatan. Berdasarkan ceramah dan diskusi ini tim pengabdian akan dapat mengetahui ketertarikan masyarakat terhadap kegiatan pengabdian. Selain itu dapat membangun motivasi tinggi untuk meningkatkan pengetahuan dan keterampilan.

3. Rekrutmen

Rekrutmen adalah bentuk pernyataan selain mitra yang bersedia untuk mengikuti kegiatan pengabdian. Masyarakat sekitar yang bersedia selanjutnya dibimbing untuk mengikuti jadwal kegiatan pengabdian, sedangkan bagi yang tidak bersedia tentunya tidak dikutsertakan lagi dalam kegiatan pengabdian selanjutnya. Kegiatan rekrutmen ini bersifat sukarela tanpa ada paksaan ataupun tekanan dari siapapun.

4. Pelatihan Membuat Kue Jajanan Pasar

Pelatihan yang akan dilakukan dimulai dari pemilihan bahan baku, membuat adonan, mencetak sampai memasak produk kue. Pelatihan akan mengundang orang yang memang sudah diakui keahliannya dalam membuat aneka ragam jenis kue tradisonal jajanan pasar. Diperkirakan ada sebanyak 2-3 orang yang akan menjadi pelatih dalam pembuatan kue ini. Dalam pelatihan ini maka tim pengabdian akan memfasillitasi dan menyediakan semua bahan-bahan dan peralatan yang diperlukan dalam pembuatan kue tersebut. Pelatihan ini diharapkan akan meningkatkan keterampilan para mitra.

5. Pelatihan proses produksi yang baik

Pelatihan dilakukan agar mitra dapat memproduksi kue lebih banyak dan hemat waktu. Sehingga dapat meningkatkan jumlah produk yang berdampak pada peningkatan pendapatan pelaku usaha. Dalam pelatihan ini tim pengabdian juga akan memfasillitasi dan menyediakan semua bahan-bahan dan peralatan yang diperlukan dalam proses produksi (mengadon dan memasak) kue tersebut.

6. Pelatihan strategi pemasaran

Dalam pelatihan ini tim pengabdian akan mengajarkan bagaimana cara memasarkan produk kue jajanan pasar. Sehingga wilayah pemasaran tidak terbatas di sekitar rumah saja. Selain itu juga memberi pelatihan agar memiliki mental kewirausahaan serta mampu dan percaya diri dalam mengembangkan usahanya.

7. Evaluasi

Evaluasi akan dilakukan selama pelaksanaan kegiatan pengabdian yang meliputi pengamatan keterampilan dalam pembuatan hingga packaging (pengemasan) produk kue jajanan pasar dan pengamatan dalam strategi pemasaran. Selain itu juga evaluasi akan dilakukan meskipun kegiatan pelatihan sudah selesai, yaitu dengan bertelepon menanyakan kemajuan usaha selama ini dan juga dengan mengunjungi kembali dan menanyakan keuntungan dan hambatan yang dijumpai setelah kegiatan pelatihan selesai dilakukan. 


\subsection{Kontribusi Partisipasi Mitra}

1. Mitra bersedia mengikuti segala bentuk pelatihan dan berniat untuk merubah cara kerja menjadi lebih efisien dan efektif.

Mitra akan diminta supaya aktif dan membiasakan diri untuk berkomitmen membuat kuejajanan pasar yang sesuai dengan selera pasar.

2. Mitra bersedia mengikuti pelatihan strategi dalam pemasaran yang akan dipraktekkan oleh mitra untuk menjamin keberhasilan usaha mereka.

Mitra bersedia menerapkan apa yang telah diajarkan pada pelatihan dan bersedia dievaluasi. Pengukuran kinerja mereka akan terus dipantau, sehingga pendapatan mitra pengusaha meningkat.

3. Mitra bersedia juga mengikuti pelatihan dalam menghitung total pendapatan, mengetahui faktor-faktor yang menentukan besarnya pendapatan.

Mitra mampu menghitung total biaya dan mengetahui cara untuk meminimalkan biaya produksi serta mampu menghitung keuntungan per satuan produksi dan total keuntungan per bulan.

4. Mitra bersedia dan diteguhkan untuk membangun karakter pengusaha agar mengubah pola kerja.

Mitra pengusaha mampu meningkatkan produksi dan produktivitasnya sehingga semakin mandiri secara ekonomis.

\section{HASIL DAN PEMBAHASAN}

Jajanan pasar adalah makanan tradisional Indonesia yang diperjual belikan di pasar, khususnya di pasar-pasar tradisional. Sampai saat ini jajanan pasar masih diminati oleh masyarakat karena jajanan pasar bukan cuma harganya yang terjangkau saja tapi rasanya juga enak dan jenisnya yang beragam serta mudah sekali untuk didapatkan. Pembuatan kue-kue ini juga rata-rata memakai bahan-bahan dan cara yang tradisional. Bahan baku utama seperti tepung beras, ketan, ubi, pisang dan kelapa adalah bahan yang sering digunakan untuk membuat kue-kue tradisional.

Mitra pengabdian memutuskan untuk membuka usaha kue jajanan pasar karena didorong untuk mendapatkan tambahan penghasilan. Ditambah lagi dia melihat ada peluang dagang yang bagus. Dimana kebetulan rumahnya dekat dengan pabrik-pabrik.

Sekarang usahanya telah mulai berkembang. Dia sudah mulai menerima banyak pesanan baik dari warga di sekitar tempat tinggalnya maupun dari luar desa nya. Banyaknya pesanan ini tentu membuat keuntungan yang diperoleh juga meningkat. Namun dia juga harus menjaga kualitas kuenya tetap baik atau bahkan meningkat agar pelanggannya tidak meninggalkannya. Disamping itu dia harus berusaha memberikan pelayanan terbaik agar pelanggan merasa puas dan senang.

Untuk menyikapinya tim pengabdian memberikan penyuluhan dan pelatihan kepada mitra Penyuluhan bagaimana pentingnya menjaga kebersihan dan higienitas kue, pelatihan mengembangkan produk dengan membuat variasi-variasi produk serta juga pelatihan dalam mengemas kue hasil produksi.

\section{KESIMPULAN DAN SARAN}

\subsection{Kesimpulan}

1. Kegiatan pengabdian berlangsung dengan baik dan memperoleh sambutan yang besar dari mitra.

2. Telah terjadi peningkatan produksi dan produktivitas mitra. 


\subsection{Saran}

Hendaknya kegiatan pengabdian dan pendampingan kepada masyarakat dapat terus dilakukan dan jangkauan serta volumenya supaya lebih ditingkatkan agar keberadaan Universitas Sumatera Utara dapat lebih dirasakan oleh masyarakat luas.

\section{UCAPAN TERIMAKASIH}

Tim pengabdian pada masyarakat mengucapkan terima kasih kepada pihak LPPM USU yang telah memberikan dana kepada pengabdian ini. Terima kasih juga kepada pihak mitra yang telah koopratif di dalam pelaksanaan pengabdian ini.

\section{DAFTAR PUSTAKA}

Alma, Buchari. (2008). Manajemen Pemasaran dan Pemasaran Jasa. Penerbit Alfabeta, Bandung.

Brigham, Eugene $\mathrm{F}$ and Joel F Houston, 2004, Fundamentals of Financial Management, 10e, International Student Edition, Thomson Learning.

Cravens, David W. (2009). Strategic Marketing. Seventh Edition. Boston: Irwin McGraw-Hill

Ferdinand, Augusty. (2002), Marketing Strategy Making: Proses dan Agenda Penelitian, Journal Sains Pemasaran Indonesia. Vol 1, No.1, Mei, p.1-22.

Hisrich\& Peters, 2002, Entrepreneurship, Fifth Edition.New York:McGraw-Hill Higher Education

Kotler, Phillip, 2008, Marketing Management - The Millenium Edition, Prentice Hall.

Salvatore, Dominick. 2005. Managerial Economics. Edisi Kelima. Jilid Pertama.Jakarta: Salemba Empat.

Suryana, 2006, Kewirausahaan Pedoman Praktis : Kiat dan Proses Menuju Sukses, Jakarta:Salemba Empat.

Sutojo, Siswanto, 2003, Manajemen Penjualan yang Efektif, PT. Darma Mulia Pustaka.

Van Horne, James and John M. Machowics, JR, 2001, Pinciple of Financial Management, Prentice Hall. 